\title{
PENINGKATAN KETERAMPILAN MENULIS PARAGRAF ARGUMENTASI MELALUI MODEL GROUP INVESTIGATION SISWA KELAS X SMA NEGERI 1 WONOMULYO
}

\author{
Alwi \\ SMA Negeri 1 Wonomulyo \\ Email: alwiahmad1966@gmail.com
}

\begin{abstract}
This study aims to describe the improvement of the learning process for writing argumentative paragraphs through a group investigation model for X6 grade students at $S M A$ Negeri 1 Wonomulyo. This type of research is classroom action research which is carried out in two cycles. The subjects in this study were 39 students. Data collection is done by writing paragraphs in the form of argumentation tests and observations. Data were analyzed quantitatively and qualitatively. The results showed that the number of students who were active in choosing subject matter, exercises in determining facts or evidence that support paragraphs based on observations made, writing argumentative paragraphs, teacher performance in directing students, assigning students to choose subject matter, looking for references then conducting investigations, and writing argumentative paragraphs in the first cycle is $60,16 \%$ while in the second cycle it is $80,55 \%$. The results of paragraph learning based on six aspects of scoring include argumentative characteristics, alignment of content with the subject matter, content organization, use of language (effective sentences), accuracy and accuracy of diction, and spelling and reading showed improvement. In the first cycle, the average value of writing argumentative paragraphs obtained was 71,53 with a sufficient score, students who got a score of 75 were 11 students (28,20\%). In cycle II, the average value of writing argumentative paragraphs was 81.74 with good scores. Students who got a score of 75 were 33 students $(84,16 \%)$. This shows that the learning outcomes have met the standard of success, namely $75 \%$.
\end{abstract}

Keywords: writing skills, argumentation paragraphs, model group investigation

\section{PENDAHULUAN}

Terdapat empat keterampilan berbahasa dalam pembelajaran bahasa Indonesia yang butuh dipahami siswa yaitu: menyimak, berbicara, membaca, dan menulis. Sebagai keterampilan berbahasa, menulis merupakan aktivitas berkomunikasi untuk menyalurkan informasi secara tertulis kepada pihak lain. Menulis adalah aktivitas yang komprehensif karena siswa dituntut agar dapat 
merangkai serta meraknai isi tulisan dan menuangkannya dalam ragam bahasa tulis.

Aktivitas menulis memiliki manfaat bagi kehidupan sehari-hari. Khususnya dalam melaksanakan pembelajaran, siswa mampu menambah kepandaian, mengembangkan daya inovatif dan kreativitas, meningkatkan sifat berani, serta membangkitkan kegigihan dan kecakapanan merangkum informasi. Kecakapan menulis juga tidak akan datang secara otomatis, tetapi harus melalui latihan yang banyak dan teratur.

Mengingat pentingnya keterampilan menulis bagi siswa, maka dalam pembelajaran bahasa Indonesia khususnya keterampilan menulis paragraf argumentasi, guru butuh mempraktikkan strategi belajar yang tepat dan efektif. Keberhasilan pencapaian tujuan pembelajaran salah satunya sangat ditentukan oleh strategi belajar. Mengaplikasikankan strategi belajar yang tepat mampu menunjang kecakapan siswa untuk menguasai bahan ajar dan relevansinya bagi kehidupan sehari-hari.

Salah satu keterampilan berbahasa yang butuh dimilik oleh siswa adalah keterampilan menulis paragraf argumentasi. Paragraf argumentasi merupakan tulisan yang berisi opini yang diiringi dengan data dan fakta yang tujuannya berusaha mengubah keyakinan pembaca dengan jalan menerangkan fakta-fakta untuk membuktikan kebenaran pendapatnya.

Paragraf argumentasi adalah bentuk tulisan yang dapat mempermudah siswa mengatasi masalah dalam menulis, mengungkapkan kejadian yang pernah dialami (pengalaman) mereka.

Pengalaman yang dimiliki oleh siswa dapat berupa kejadian personal di lingkungan keluarga, sekolah, dan masyarakat umum. Hal yang dirasakan siswa di lingkungan sekitar merupakan sumber tulisan argumentasi yang sangat menarik dan mudah untuk dijadikan bahan pengembangan tulisan.

Di lingkungan sekitar, banyak hal yang bisa dijadikan sebagai sumber ide penulisan argumentasi yang dapat diperhatikan dari lingkungan kehidupan manusia. Hal yang tidak bisa dipungkiri ternyata masih banyak calon penulis yang kebingungan untuk menginterpretasikan suatu kejadian untuk diolah menjadi tulisan yang argumentatif. Banyak penulis pemula belum mengetahui cara menyusun tulisan yang sistematis, cara mengawali tulisan untuk menuangkan ide dalam kalimat yang efektif. Selain itu, siswa yang kurang respon selama mengikuti aktivitas menulis paragraf argumentasi. Siswa lebih meyukai komunikasi secara lisan karena lebih mudah dipraktekkan dibandingkan menuangkan gagasan melalui tulisan. Hal inilah yang kerap dirasakan oleh siswa dalam proses pembelajaran menulis paragraf argumentasi.

Keadaan tersebut yang menggugah perhatian saya selaku guru Bahasa Indonesia untuk mengatasi masalah pembelajaran menulis paragraf argumentasi melalui pemanfaatan model pembelajaran yang inovatif. Pengaplikasian model 
pembelajaran yang inovatif sangat dianjurkan sehingga aktivitas pembelajaran dapat lebih efektif. Salah satu model pembelajaran inovatif adalah model pembelajaran kooperatif. Melalui pembelajaran kooperatif siswa menjadi lebih muda mengetahui konsep yang sukar jika siswa saling berdiskusi, berpikir kritis dan kreatif untuk mencapai ketuntasan belajar. Bertolak dari pemikiran tersebut, penulis meneliti Pemanfaatan salah satu model pembelajaran kooperatif yaitu model Group Investigation dalam menulis paragraf argumentasi. Penelitian tindakan kelas ini didasarkan pada adanya tindakan tertentu untuk memperbaiki atau meningkatkan mutu dan hasil pembelajaran menulis paragraf argumentasi.

Pemanfaatan Model Group Investigation dalam pembelajaran menulis paragraf argumentasi menekankan siswa aktif dan mengembangkan daya kritisnya. Selaras dengan karakteristik model Group Investigation, penggunaan model ini sebagai alternatif pembelajaran menulis paragraf argumentasi diharapkan dapat mengarahkan siswa terlibat aktif dalam proses bernalar kritis, analisis, dan sintesis terhadap suatu informasi yang dituangkan dalam tulisan argumentasi. Selain itu diharapkan dapat menurunkan rasa kejenuhan siswa dalam proses belajar menulis paragraf argumentasi. Model ini juga diharapkan dapat mendukung siswa untuk menyadari makna belajar, manfaat belajar, mengembangkan kreativitas, dan memaksimalkan potensi yang dimilikinya agar tujuan pembelajaran dapat tercapai. Berdasarkan uraian tersebut peneliti melakukan penelitian yang berjudul "Peningkatan Keterampilan Menulis Paragraf Argumentasi Melalui Model Group Investigation Siswa Kelas X SMA Negeri 1 Wonomulyo Kabupaten Polewali Mandar".

Berdasar uraian di atas, rumusan masalahan penelitian ini yaitu: (1) Bagaimanakah peningkatan proses pembelajaran menulis paragraf argumentasi melalui model Group Investigation Siswa Kelas X SMA Negeri 1 Wonomulyo Kabupaten Polewali Mandar. (2) Bagaimanakah peningkatan hasil pembelajaran menulis paragraf argumentasi melalui model Group Investigation Siswa Kelas X SMA Negeri 1 Wonomulyo Kabupaten Polewali Mandar.

Tujuan yang akan diraih dalam penelitian adalah untuk meningkatkan proses pembelajaran menulis paragraf argumentasi melalui model Group Investigation siswa kelas X SMA Negeri 1 Wonomulyo Kabupaten Polewali Mandar dan meningkatkan hasil pembelajaran menulis paragraf argumentasi melalui model Group Investigation siswa kelas X SMA Negeri 1 Wonomulyo Kabupaten Polewali Mandar.

Hasil penelitian ini diharapkan mampu memberikan manfaat, baik secara teoretis maupun praktis. Manfaat Teoretis yaitu memberikan pengetahuan mengenai penggunaan model yang inovatif dalam pembelajaran menulis paragraf argumentasi, misalnya penggunaan model Group Investigation. Manfaat praktis yaitu dalam penelitian ini diharapkan dapat memberi manfaat bagi siswa, guru, dan peneliti pendidikan, yaitu (a) Bagi siswa, yaitu memberikan peluang kepada 
siswa untuk mengungkapkan gagasan selaras pengetahuan dan pengalaman yang dimilikinya berkenaan dengan ide yang akan ditulis dalam paragraf argumentasi (b) Bagi guru, dijadikan sebagai model pembelajaran yang inovatif dan menarik khususnya dalam pembelajaran menulis paragraf argumentasi.

Menulis adalah menyusun huruf (angka dsb.) menggunakan pena (pensil, kapur, dsb.); menghasilakn ide pikiran atau perasaan (seperti mengarang, membuat surat) dengan tulisan (Depdiknas, 2008: 1497). Di sisi lain Sumarjo (dalam Komaidi, 2011: 5) berpendapat bahwa menulis adalah suatu proses menghasilkan tulisan yang mengandung gagasan.

Terdapat empat unsur yang terlibat dalam aktivitas menulis yaitu penulis sebagai pembawa pesan yang berisi informasi (penulis), pesan atau informasi, saluran atau media berupa tulisan, dan pembaca sebagai penerima informasi.

Adapun tujuan menulis menurut Hartig (dalam Tarigan, 2008: 25-26) adalah:

1) Untuk menarik perhatian para pembaca, menghindarkan kesedihan para pembaca, ingin membantu para pembaca mendalami, menghormati perasaan dan pemikirannya, hendak membuat hidup para pembaca lebih nyaman dan lebih menarik dengan karyanya itu (tujuan altuiristik).

2) Untuk menyelesaikan tugas, contohnya siswa/i diberikan tugas merangkumkan jurnal/buku bacaan; sekretaris yang ditugaskan menyusun laporan atau notulensi rapat (tujuan penugasan).

3) Untuk meyakinkan para pembaca atas kebenaran ide gagasan yang disampaiakan dalam tulisan (tugas persuasif).

4) Untuk menyalurkan pesan atau informasi kepada para pembaca (tujuan informasional, tujuan penerangan).

5) Untuk memperkenalkan diri sang penulis kepada para pembaca (tujuan pernyataan diri).

6) Untuk melibatkan diri pengarang dengan keindahan menggapai norma artistik, atau seni yang ideal, seni idaman (tujuan kreatif).

7) Untuk memecahkan masalah yang dihadapi (tujuan pemecahan masalah). a. Tahap-Tahap Menulis

Menurut Semi (2007: 46-52) tahapan menulis terbagi atas tiga tahap, yaitu:

1) Tahap pratulis

Aktivitas pada tahap pratulis terdiri atas empat jenis, yaitu:

Pertama, menetapkan topic yaitu menentukan pilihan secara efisien dari berbagai sumber pokok pembicaraan yang tersedia. Penulis pada fase ini, mempertimbangkan menyenangkan atau tidaknya sebuah pokok pembicaraan. Dalam kaitan ini, yang diperhatikan adalah nilai pokok pembicaraan tersebut ditinjau dari kepentingan pembaca. Selain itu, dipertimbangkan juga apakah pokok pembicaraan tersebut dapat dikembangkan oleh penulis, dan apakah 
penulis mampu mendapatkan bacaan pendukung yang dapat membuat pokok pembicaraan menjadi lebih komprehensif tersebut (Semi, 2007: 46).

Kedua, menentukan tujuan yaitu mentapkan apa yang ingin diraih atau diharapkan penulis dengan tulisan yang hendak disusunnya. Setiap penulis mesti menyadari mana dari tujuan ini yang hendak diraih. Mengetahui tujuan sangat penting karena penulis dapat mengarahkan tulisan tersebut selaras dengan apa yang diinginkan oleh penulis, dan memilih cara pemaparan yang lebih tepat (Semi, 2007: 46).

Ketiga, menghimpun data-data pendukung yaitu sebuah pokok pembicaraan yang dipilih menjadi layak ditulis setelah dikumpulkan informasi yang memadai tentang pokok pembicaraan contohnya pendapat beberapa pakar. Setelah semua dianggap komplit, kemudian sebuah pokok pembicaraan layak untuk dituliskan (Semi, 2007: 47).

Keempat, mendesain tulisan yaitu pokok pembicaraan tulisan yang telah ditetapkan dipilah-pilih menjadi subpokok pembicaraan. Hasil pemilihan ini disusun dalam suatu kerangka tulisan atau outline. Kerangka tulisan ini akan sangat membantu penulis dalam menuntaskan tulisan (Semi, 2007: 47).

\section{Pengertian Paragraf}

Pada hakikatnya, paragraf adalah satu kesatuan atau keutuhan pikiran yang lebih luas daripada kalimat. Setiap paragraf berisi satu gagasan dasar yang diungkapkan dalam kalimat pokok pembicaraan dan sejumlah gagasan penjelas yang diungkapkan ke dalam kalimat penjelas. Menurut Arifin (2010: 115) paragraf merupakan seperangkat kalimat yang membicarakan suatu gagasan. Kalimatkalimat dalam paragraf menunjukkan kesatuan pikiran atau mempunyai keterkaitan dalam menyusun gagasan tersebut.

Kridalaksana (2008: 173) mengemukakan bahwa paragraf merupakan (a) satuan bahasa yang berisi satu topik dan perkembangannya, (b) bagian wacana yang menerangkan pikiran atau hal tertentu yang lengkap, tetapi yang masih berkaitan dengan isi seluruh wacana, dapat terjadi dari suatu kalimat atau kelompok kalimat yang berhubungan.

\section{Argumentasi}

Argumentasi adalah salah satu jenis pengembangan paragraf dalam penulisan yang ditulis dengan maksud untuk meyakinkan atau membujuk. Keraf (2000: 3) berpendapat, argumentasi adalah suatu bentuk retorika yang berupaya untuk membujuk dan pempengaruhi sikap dan opini orang lain agar mereka percaya dan akhirnya berlaku selaras dengan apa yang diharapkan oleh penulis atau pembicara. Melalui argumentasi penulis berupaya menyusun bukti-bukti nyata sedemikian rupa sehingga penulis cakap dalam menerangkan suatu opini atau suatu kejadian tertentu benar atau tidak.

Kaidah- Kaidah Penulisan Argumentasi 
Menurut Weston (2007: 9) ada beberapa kaidah-kaidah umum untuk menyusun argumen-argumen pendek, antara lain:

1) Bedakan premis dan kesimpulan

Kesimpulan adalah suatu pernyataan yang diberikan alasan-alasan. Pernyataan yang memberikan alasan-alasan disebut premis.

2) Sampaikan gagasan dengan urutan yang alami

Ajukan kesimpulan terlebih dahulu, diikuti oleh alasan-alasan penulis atau letakkan premis-premis dahulu dan tariklah kesimpulan di bagian akhir

3) Mulailah dengan premis yang bisa dipercaya

4) Konkret dan ringkaslah; hindari istilah-istilah abstrak, samar, dan umum.

5) Hindari bahasa yang berlebihan (Loaded Language)

6) Gunakan istilah-istilah yang konsisten

7) Pancangkan satu makna untuk tiap istilah

a. Langkah-Langkah Penyusunan Argumentasi

Langkah-langkah penyusunan argumentasi (Suparno dan Yunus, 2010:

5.40-5.41):

1) menentukan tema/pokok pembicaraan argumentasi

2) menentukan tujuan berargumentasi

3) menyusun kerangka argumentasi berdasarkan tema/pokok pembicaraan

4) menghimpun fakta, data, informasi, dan bukti yang selaras dengan kerangka argumentasi. Bukti informasi dapat diperoleh dengan cara menghimpun fakta dan kesaksian dari orang yang memiliki kredibilitas tinggi karena pakar dalam bidang tertentu dan mempunyai otoritas. Selain itu, penulis dapat pula melakukan penelitian dan pengamatan langsung melalui: (1) Kegiatan penelitian lapangan berulang-ulang sehingga diperoleh data yang komprehensif, (2) melaksanakan interview dengan narasumber dan responden, (3) membaca jurnal/buku-buku yang mengandung fakta atau bukti-bukti yang dibutuhkan.

5) Setelah fakta dan bukti didapatkan, penulis meneliti dan menilai fakta yang benar-benar mendukung pokok pembicaraan dan tujuan argumentasi

6) Menyusun paragraf argumentasi selaras tema/pokok pembicaraan dan tujuan argumentasi

b. Aspek Pemberian nilai Paragraf Argumentasi

Nurgiyantoro (2010: 439) menerangkan bahwa pemberian nilai terhadap hasil karangan siswa sebaiknya juga memanfaatkan rubrik pemberian nilai yang mengandung komponen isi dan bahasa masing-masing dengan subkomponennya. Tiap komponen diberi skor secara mandiri dan skor keseluruhan diperoleh dengan menjumlah skor-skor komponen tersebut. Melalui metode ini akan didapatkan isi pesan komponen yang skornya tinggi atau yang rendah dan itu mencerminkan tingkat kompetensi peserta didik. Rubrik pemberian nilai yang dimaksud dicontohkan di bawah. 
Contoh Rubrik Pemberian nilai Mengarang dengan Tema Tertentu

\begin{tabular}{|c|c|c|c|c|c|c|}
\hline \multirow{2}{*}{ No. } & \multirow{2}{*}{ Aspek yang Dinilai } & \multicolumn{5}{|c|}{ Tingkat Capaian Kinerja } \\
\hline & & 1 & 2 & 3 & 4 & 5 \\
\hline 1. & Kualitas isi karangan & & & & & \\
\hline 2. & Keakuratan dan keluasan isi & & & & & \\
\hline 3. & Organisasi penulisan & & & & & \\
\hline 4. & Kebermaknaan keseluruhan tulisan & & & & & \\
\hline 5. & Ketepatan diksi & & & & & \\
\hline 6. & Ketepatan kalimat & & & & & \\
\hline 7. & Ejaan dan tata tulis & & & & & \\
\hline 8. & Kelengkapan sumber rujukan & & & & & \\
\hline
\end{tabular}

\section{Model Group Investigation}

(Nurgiyantoro (2010: 439)

Group Investigation (investigasi golongan) merupakan salah satu model pembelajaran kooperatif. Menurut Trianto (2010: 78) Group Investigation (investigasi golongan) adalah model pembelajaran kooperatif yang paling komprehensif dan paling sukar diterapkan. Model Group Investigation mengarah pada aktivitas perolehan, analisis, dan sintesis informasi dalam usaha untuk menemukan solusi. Oleh karena itu, keberhasilan implementasi model ini sangat tergantung dari pelatihan awal dalam penguasaan keterampilan komunikasi dan sosial.

Dalam implementasi model Group Investigation (investigasi kelompok) guru membagi kelas menjadi golongan-golongan dengan beranggotakan 5-6 siswa yang heterogen. Golongan di sini dapat dibentuk dengan mempertimbangkan keakraban, persahabatan atau minat yang sama dalam pokok pembicaraan tertentu. Selanjutnya siswa memilih pokok pembicaraan untuk diselidiki, dan melakukan penyelidikan yang mendalam atas pokok pembicaraan yang dipilih. Selanjutnya siswa menyiapkan dan memaparkan laporannya kepada seluruh kelas.

Sharan (dalam Trianto, 2010: 80) membagi tahap-tahap pelaksanaan model Group Investigation (investigasi golongan) meliputi enam fase, antara lain:

a. Memilih pokok pembicaraan

Siswa memilih subpokok pembicaraan khusus di dalam suatu daerah masalah umum yang biasanya ditetapkan oleh guru. Selanjutnya siswa diorganisasikan menjadi dua sampai enam anggota tiap golongan menjadi golongan-golongan yang berorientasi tugas. Komposisi anggota setiap golongan sebaiknya heterogen secara akademis maupun etnis.

b. Perencanaan Kooperatif 
Siswa dan guru menyusun rencana tata cara pembelajaran, tugas dan tujuan khusus yang konsisten dengan subpokok pembicaraan yang telah dipilih pada tahap pertama.

c. Implementasi

Siswa mempraktikkan rencana yang telah mereka kembangkan di dalam tahap kedua. Aktivitas pembelajaran hendaknya melibatkan ragam aktivitas dan keterampilan yang luas dan hendaknya mengarahkan siswa kepada jenis-jenis sumber belajar yang berbeda baik di dalam atau di luar sekolah. Guru secara ketat mengikuti kemajuan tiap golongan dan menawarkan bantuan bila dibutuhkan.

d. Analisis dan Sintesis

Siswa menganalisis dan mensintesis informasi yang didapatkan pada tahap ketiga dan menyusun rencana bagaimana informasi tersebut dirangkum dan dipaparkan dengan cara yang menarik sebagai bahan untuk ditampilkan kepada seluruh kelas.

\section{e. Presentasi Hasil Final}

Beberapa atau semua golongan memaparkan hasil penelusurannya dengan cara yang menarik kepada seluruh kelas, dengan tujuan agar siswa yang lain saling terlibat satu sama lain dalam pekerjaan mereka dan mendapatkan perspektif luas pada pokok pembicaraan itu. Presentasi dikoordinasikan oleh guru.

f. Evaluasi

Dalam hal golongan-golongan menangani aspek yang berbeda dari pokok pembicaraan yang sama, siswa dan guru mengevaluasi tiap kontribusi kelompok terhadap kerja kelas sebagai suatu keseluruhan. Evaluasi yang dilakukan dapat berupa pemberian nilai secara mandiri atau golongan.

\section{METODE PENELITIAN}

Penelitian ini menggunakan metode penelitian tindakan (Action Reserch), khususnya penelitian tindakan kelas (Classroom Action Reserch). Penelitian ini menggunakan pemaparan data deskriptif kualitatif dan data kuantitatif. Data kualitatif diperoleh dari hasil wawancara, hasil observasi, dan keaktifan siswa dalam setiap tindakan dan data kuantitatif diperoleh dari hasil tes akhir setiap siklus.

Dalam penelitian ini dilakukan dalam sebanyak dua siklus yang saling berkaitan. Jika pelaksanaan pada siklus 1 belum sukses maka akan dilanjutkan ke siklus II sebagai perbaikan dari pelaksanaan siklus I.

Subjek dalam penelitian ini adalah siswa kelas X SMA Negeri I Wonomulyo Kabupaten Polewali Mandar yang jumlah siswanya 39 siswa terdiri atas 15 siswa putra dan 24 siswa putri, serta guru bahasa Indonesia kelas tersebut.

Sumber data pada penelitian ini adalah data dalam proses dan data hasil pembelajaran. Data dalam proses penelitian ini meliputi aktivitas yang dikakukan dalam proses dan data hasil penelitian berupa data proses dan data produk. Data 
proses diperoleh dengan cara mengamati aktivitas siswa selama mengikuti pembelajaran menulis paragraf argumentasi melalui model Group Investigation. Data produk berupa hasil tes dengan melihat kecakapan dan keterampilan siswa dalam menulis paragraf argumentasi melalui model Group Investigation yang memenuhi enam aspek pemberian nilai meliputi keselarasan isi selaras karakteristik argumentasi, keselarasan isi dengan pokok pembicaraan, organisasi isi, penggunaan kebahasaan (kalimat efektif), ketepatan diksi (pilihan kata), dan ejaan dan tanda baca. Tes tersebut dilakukan tiap akhir siklus.

Instrumen yang digunakan dalam penelitian ini meliputi format observasi dan tes unjuk kerja bagi siswa. Teknik yang digunakan untuk menghimpun data dalam penelitian, yaitu observasi dan tes.

Teknik analisis data dilakukan secara kuantitatif dan kualitatif. Teknik kuantitatif digunakan untuk menganalisis data yang didapatkan dari hasil tes menulis paragraf argumentasi pada siklus I dan II sedangkaan teknik kualitatif digunakan untuk menganlisis data yang didapatkan dari non tes. Hasil analisis digunakan untuk mengetahui kesukaran siswa dalam proses menulis paragraf argumentasi.

\section{Kriteria Pemberian nilai}

Kecakapan siswa dalam menulis paragraf argumentasi didasarkan dari lima hal pokok meliputi (1) keselarasan isi dengan karakteristik argumentasi (2) keselarasan isi dengan pokok pembicaraan, (3) organisasi isi, (4) penggunaan bahasa (kalimat efektif), (5) ketepatan diksi (pilihan kata), dan (6) ejaan dan tanda baca.

Kelima hal pokok tersebut digambarkan dalam tabel berikut.

\begin{tabular}{|c|c|c|c|}
\hline No. & Aspek Pemberian nilai & Kriteria & Skor \\
\hline \multirow{4}{*}{1.} & \multirow{4}{*}{$\begin{array}{l}\text { Keselarasan isi dengan } \\
\text { karakteristik argumentasi }\end{array}$} & $\begin{array}{l}\text { Mengemukakan pendapat selaras } \\
\text { dengan pokok pembicaraan, } \\
\text { memaparkan fakta yang mendukung, } \\
\text { ada simpulan }\end{array}$ & 4 \\
\hline & & $\begin{array}{l}\text { Mengemukakan pendapat selaras } \\
\text { dengan pokok pembicaraan, } \\
\text { memaparkan fakta yang mendukung, } \\
\text { tidak ada simpulan }\end{array}$ & 3 \\
\hline & & $\begin{array}{l}\text { Mengemukakan pendapat selaras } \\
\text { dengan pokok pembicaraan, } \\
\text { memaparkan fakta yang kurang } \\
\text { mendukung, tidak ada simpulan }\end{array}$ & 2 \\
\hline & & $\begin{array}{l}\text { Mengemukakan pendapat tidak } \\
\text { selaras dengan pokok pembicaraan, } \\
\text { memaparkan fakta yang kurang } \\
\text { mendukung, tidak ada simpulan }\end{array}$ & 1 \\
\hline
\end{tabular}




\begin{tabular}{|c|c|c|c|}
\hline \multirow{4}{*}{2.} & \multirow{4}{*}{$\begin{array}{l}\text { Keselarasan isi dengan } \\
\text { pokok pembicaraan }\end{array}$} & $\begin{array}{l}\text { Paragrafnya menarik dibaca, } \\
\text { memaparkan pokok pembicaraan yang } \\
\text { diajukan }\end{array}$ & 4 \\
\hline & & $\begin{array}{llr}\text { Paragrafnya } & \text { menarik dibaca, kurang } \\
\text { mampu } & \text { memaparkan } & \text { pokok } \\
\text { pembicaraan yang diajukan } & \\
\end{array}$ & 3 \\
\hline & & $\begin{array}{llr}\text { Paragrafnya } & \text { kurang menarik dibaca, } \\
\text { mampu } & \text { memaparkan } \\
\text { pembicaraan yang diajukan }\end{array}$ & 2 \\
\hline & & $\begin{array}{l}\text { Paragrafnya kurang menarik dibaca, } \\
\text { kurang mampu memaparkan pokok } \\
\text { pembicaraan yang diajukan }\end{array}$ & 1 \\
\hline \multirow{4}{*}{3.} & \multirow{4}{*}{ Organisasi isi } & $\begin{array}{l}\text { gagasan diungkapkan dengan jelas, } \\
\text { tertata dengan baik, urutan logis, } \\
\text { kohesif }\end{array}$ & 4 \\
\hline & & $\begin{array}{l}\text { gagasan diungkapkan dengan jelas, } \\
\text { kurang tertata dengan baik, urutan } \\
\text { logis, kohesif }\end{array}$ & 3 \\
\hline & & $\begin{array}{l}\text { gagasan diungkapkan dengan jelas, } \\
\text { kurang tertata dengan baik, urutan } \\
\text { tidak logis, kohesif }\end{array}$ & 2 \\
\hline & & $\begin{array}{l}\text { gagasan diungkapkan dengan tidak } \\
\text { jelas, kurang tertata dengan baik, } \\
\text { urutan tidak logis, tidak kohesif }\end{array}$ & 1 \\
\hline \multirow{4}{*}{4.} & \multirow{4}{*}{$\begin{array}{l}\text { Penggunaan } \quad \text { bahasa } \\
\text { (kalimat efektif) }\end{array}$} & $\begin{array}{l}\text { Kalimat lancar, cermat, meskipun } \\
\text { sedikit ada kesalahan tata bahasa }\end{array}$ & 4 \\
\hline & & $\begin{array}{l}\text { Kalimat lancar, cermat, tetapi ada } \\
\text { beberapa kesalahan tata bahasa yang } \\
\text { menyebabkan kalimat yang rancu }\end{array}$ & 3 \\
\hline & & $\begin{array}{l}\text { Ada beberapa hal yang tidak dapat } \\
\text { dipahami }\end{array}$ & 2 \\
\hline & & $\begin{array}{l}\text { Kalimat dalam paragraf tidak bisa } \\
\text { dipahami }\end{array}$ & 1 \\
\hline \multirow[b]{2}{*}{5.} & \multirow{2}{*}{$\begin{array}{l}\text { Ketepatan diksi (pilihan } \\
\text { kata) }\end{array}$} & $\begin{array}{l}\text { Pilihan kata dan ungkapan tepat, } \\
\text { menguasai pembentukan kata }\end{array}$ & 4 \\
\hline & & $\begin{array}{l}\text { Pilihan kata dan ungkapan kadang- } \\
\text { kadang kurang tepat tetapi tidak } \\
\text { mengganggu }\end{array}$ & 3 \\
\hline
\end{tabular}




\begin{tabular}{|l|l|l|c|}
\hline & & $\begin{array}{l}\text { Sering terjadi kesalahan penggunaan } \\
\text { kosakata dan dapat merusak makna }\end{array}$ & 2 \\
\cline { 3 - 4 } & $\begin{array}{l}\text { Penggunaan kosakata asal-asalan, } \\
\text { pengetahuan tentang kosakata rendah }\end{array}$ & 1 \\
\hline \multirow{3}{*}{6.} & \multirow{2}{*}{ Ejaan dan tanda baca } & Jumlah kesalahan kurang dari lima & 4 \\
\cline { 3 - 4 } & Jumlah kesalahan antara 5-10 & 3 \\
\cline { 3 - 4 } & Jumlah kesalahan 10-15 & 2 \\
\cline { 3 - 4 } & Jumlah kesalahan lebih dari lima belas & 1 \\
\hline & & 24 \\
\hline
\end{tabular}

(Modifikasi dari Nurgiyantoro, 2010:439-441) dan Sukarina (2011: 46-47)

Pemberian nilai dilakukan dengan rumus:

$$
\text { Nilai }=\frac{\text { skorperolehan }}{\text { skormaksimal }} \times 100
$$

\section{Standar Keberhasilan}

Pemanfaatan model group investigation dalam usaha meningkatkan keterampilan menulis paragraf argumentasi siswa kelas X SMA Negeri 1 Wonomulyo Kabupaten Polman dikaitkan dengan ketuntasan belajar. Kriteria Ketuntasan Minimal (KKM) pelajaran Bahasa Indonesia sekolah tersebut adalah nilai 75. Berpijak pada nilai KKM tersebut, standar keberhasilan Pemanfaatan model group investigation dalam pembelajaran menulis paragraf argumentasi dikatakan berhasil jika siswa mendapat nilai $\geq 75$.

Peningkatan keterampilan menulis paragraf argumentasi melalui group investigation dilihat dari data proses dan data hasil. Data proses diperoleh dari aktivitas atau unjuk kerja siswa dalam pelaksanaan pembelajaran menulis paragraf argumentasi melalui model group investigation. Aktivitas atau unjuk kerja siswa berupa perhatian, antusias, keaktifan siswa, percaya diri, dan motivasi dalam belajar yang diperoleh melalui format observasi dan wawancara dikatakan berhasil apabila mencapai peringkat baik atau $\geq 75$. Sama halnya dengan unjuk kerja guru berupa aktivitas yang dilakukan dalam proses pembelajaran menulis paragraf argumentasi melalui model group investigation dikatakan berhasil jika mencapai peringkat baik atau $\geq 75$. Sementara itu data hasil yang diperoleh dari hasil tes menulis paragraf argumentasi yang menggambarkan prestasi akademik siswa dikatakan berhasil apabila $\geq 75$ siswa mendapatkan peringkat baik. 
Tabel 1. Penentuan Patokan Tingkat Penguasaan

\begin{tabular}{|l|l|l|}
\hline No. & $\begin{array}{l}\text { Interval } \\
\text { Tingkat } \\
\text { Penguasan }\end{array}$ & Keterangan \\
\hline 1. & $86-100$ & Baik Sekali \\
\hline 2. & $75-85$ & Baik \\
\hline 3. & $56-74$ & Cukup \\
\hline 4. & $10-55$ & Kurang \\
\hline
\end{tabular}

(Adaptasi dari Nurgiyantoro, 2010: 253)

\section{HASIL DAN PEMBAHASAN}

Data hasil observasi pada aktivitas pembelajaran pada siklus I secara umum pertama pada aktivitas observasi dalam hitungan persen. Pertemuan pertama dan kedua rata-rata aktif $60,16 \%$, kurang aktif $24,99 \%$, dan tidak aktif $14,82 \%$, sedangkan pada siklus II pertemuan pertama dan kedua rata-rata aktif $80,55 \%$, kurang aktif $12,17 \%$, dan tidak aktif $7,26 \%$.

Data hasil pembelajaran pada siklus I keterampilan menulis paragraf argumentasi melalui model Group Investigation pada pertemuan pertama dan kedua yaitu:

Berdasarkan peringkat tingkat penguasaan tersebut dapat dinyatakan bahwa terdapat 11 orang $(28,20 \%)$ yang mendapatkan nilai pada peringkat baik. Peringkat cukup sebanyak 27 orang $(69,23 \%)$ dan siswa yang mendapatkan nilai pada peringkat kurang sebanyak 1 orang $(2,56 \%)$ serta tidak ada siswa yang mendapatkan nilai pada peringkat baik sekali. Dari hasil pembelajaran siswa pada pertemuan pertama dan kedua siklus I belum mencapai standar keberhasilan $75 \%$. Jumlah siswa yang mencapai nilai $\geq 75$ (nilai KKM) hanya 11 orang $(28,20 \%$ ). Berdasarkan data-data tersebut, dinyatakan bahwa Pemanfaatan model Group Investigation dalam pembelajaran keterampilan menulis paragraf argumentasi masih butuh diterapkan pada siklus selanjutnya.

Data hasil pembelajaran pada siklus II, sebanyak 10 orang $(25,64 \%)$ mendapatkan nilai pada peringkat baik sekali. Selanjutnya, siswa yang mendapatkan nilai pada peringkat baik sebanyak 23 orang $(58,97 \%)$, siswa yang mendapatkan nilai pada peringkat cukup sebanyak 6 orang $(15,38 \%)$, dan tidak ada siswa yang mendapatkan nilai pada peringkat kurang. Hal ini menunjukkan bahwa hasil pembelajaran siswa siklus II sebanyak 33 orang $(84,61 \%)$ telah mencapai nilai $\geq 75$ (nilai KKM), yaitu berada pada peringkat baik sekali dan baik, dan 6 orang $(15,38 \%)$ yang belum mencapai nilai KKM, yaitu berada pada peringkat cukup sehingga tindakan tidak butuh dilanjutkan pada siklus selanjutnya. 
Data peringkat nilai siswa dalam Keterampilan menulis paragraf argumentasi pada Siklus I dan Siklus II menunjukkan bahwa pada siklus I tidak ada siswa yang mendapatkan nilai dengan peringkat baik sekali. Peringkat baik sebanyak 11 orang $(28,20 \%)$, siswa yang mendapatkan peringkat cukup sebanyak 27 orang $(69,23 \%)$, dan hanya 1 orang $(2,56 \%)$ yang mendapatkan peringkat kurang. Pada siklus II, siswa yang mendapatkan nilai pada peringkat baik sekali sebanyak 10 orang $(25,64 \%)$, peringkat baik sebanyak 23 orang $(58,97 \%)$. Siswa yang mendapatkan nilai pada peringkat cukup sebanyak 6 orang $(15,38 \%)$, dan tidak ada siswa yang mendapatkan nilai pada peringkat kurang. Berdasarkan data tersebut, dapat dinyatakan terjadi peningkatan nilai siswa di berbagai peringkat.

Berdasarkan data nilai kecakapan siswa pada siklus I dan siklus II menunjukkan bahwa pada siklus I hanya 11 orang $(28,20 \%)$ yang mencapai nilai $\geq$ 75 (nilai Kriteria Ketuntasan Minimal) dan masih terdapat 28 orang $(71,8 \%)$ yang belum mencapai nilai KKM, yaitu berada di bawah nilai 75. Pada siklus II, siswa yang mencapai nilai $\geq 75$ sebanyak 33 orang $(84,61 \%)$ dan siswa yang belum mencapai nilai K KM sebanyak 6 orang $(15,38 \%)$. Nilai rata-rata siklus I dari 71,53 dengan peringkat cukup menjadi 81,74 dengan peringkat baik pada siklus II dengan peningkatan senilai 10,21. Berdasarkan nilai rata-rata pada siklus II yang telah mencapai nilai KKM maka dapat dinyatakan bahwa tindakan telah mencapai standar keberhasilan sehingga tidak butuh dilanjutkan ke siklus berikutnya. Hal ini menunjukkan bahwa Pemanfaatan model Group Investigation dalam meningkatkan keterampilan menulis paragraf argumentasi siswa kelas $X$ SMA Negeri 1 Wonomulyo Polman dapat dinyatakan berhasil.

\section{SIMPULAN}

Hasil pembelajaran keterampilan menulis paragraf argumentasi melalui pengaplikasian model group investigation didasarkan pada enam kriteria pemberian nilai meliputi keselarasan isi dengan karakteristik argumentasi, keselarasan isi dengan pokok pembicaraan, organisasi isi, penggunaan bahasa (kalimat efektif), ketepatan diksi (pilihan kata), ejaan dan tanda baca menunjukkan peningkatan. Peningkatan hasil pembelajaran siswa terlihat dari perubahan nilai rata-rata siswa dari siklus I ke siklus II. Pada siklus I, nilai rata-rata menulis paragraf argumentasi yang diperoleh siswa senilai 71,53 dengan peringkat cukup, siswa yang mendapatkan nilai KKM $\geq 75$ sebanyak 11 siswa $(28,20)$. Pada siklus II nilai rata-rata menulis paragraf argumentasi siswa senilai 81,74 dengan peringkat baik, siswa yang mendapatkan nilai KKM $\geq 75$ adalah 33 siswa $(84,16 \%)$. Jumlah siswa yang mengalami peningkatan nilai rata-rata menulis paragraf argumentasi dari siklus I ke siklus II sebanyak 23 siswa $(58,97 \%)$. 


\section{DAFTAR PUSTAKA}

Arifin, E. Zainal dan S. Amran Tasai. 2010. Cerdas Berbahasa Indonesia untuk Perguruan Tinggi. Jakarta: Akademika Pressindo.

Depdiknas. 2008. Kamus Besar Bahasa Indonesia. Edisi Keempat. Jakarta: Gramedia Pustaka Utama.

Keraf, Gorys. 2000. Argumentasi dan Narasi. Jakarta: Gramedia

Komaidi, Didik. 2011. Panduan Lengkap Menulis Kreatif Teori dan Praktik. Yogyakarta: Sabda Media.

Kridalaksana, Harimurti. 2008. Kamus Linguistik. Jakarta: Gramedia Pustaka Utama.

Nurgiyantoro, Burhan. 2010. Pemberian nilai Pembelajaran Bahasa. Yogyakarta: BPFE.

Semi, M. Atar. 2007. Dasar-Dasar Keterampilan Menulis. Bandung: Angkasa.

Suparno dan Mohamad Yunus. 2010. Keterampilan Dasar Menulis. Jakarta: Universitas Terbuka.

Tarigan, H.G. 2008. Menulis sebagai Suatu Keterampilan Berbahasa. Bandung: Angkasa.

Trianto. 2010. Model-Model Pembelajaran Inovatif-Progresif. Jakarta: Kencana. Weston, Anthony. 2007. Kaidah Beragumentasi. Yogyakarta: Pustaka Pelajar. 